\title{
Strain-to-strain differences within lactic and propionic acid bacteria species strongly impact the properties of cheese-A review
}

\author{
Anne Thierry ${ }^{1,2}$ - Florence Valence ${ }^{1,2}$ - Stéphanie-Marie Deutsch ${ }^{1,2}$. \\ Sergine Even ${ }^{1,2}$ • Hélène Falentin ${ }^{1,2}$. Yves Le Loir ${ }^{1,2}$. \\ Gwenaël Jan $^{1,2} \cdot$ Valérie Gagnaire ${ }^{1,2}$
}

\begin{abstract}
Lactic acid bacteria (LAB) and propionic acid bacteria (PAB) are widely used in the manufacture of cheeses and other fermented dairy products. Bacterial species used as starters are mainly chosen according to their intrinsic properties: the milk acidifying capacity for LAB starters and the aromatizing properties of $\mathrm{PAB}$, for example. Beyond the general characteristics of a bacterial species, many key phenotypic traits determining their interest for dairy applications depend on the strain within a given species. Through some examples, this review illustrates how the choice of a bacterial strain with specific technological characteristics, within a given species of LAB or PAB, can determine the final properties in the end product. This concerns the technological properties of cheeses, such as flavour, texture, and opening formation, and their functional properties, such as inhibition of undesirable microorganisms and health properties. When known, the genetic determinants of the diversity are presented. This review emphasizes the importance of preserving and exploring microbial resources at the intraspecific level, as an unending source of diversity for innovation in food fermentation.
\end{abstract}

Keywords Biodiversity $\cdot$ Lactococcus $\cdot$ Lactobacillus $\cdot$ Propionibacterium $\cdot$ Straindependency $\cdot$ Cheese $\cdot$ Organoleptic properties $\cdot$ Safety $\cdot$ Health properties

Anne Thierry

anne.thierry@rennes.inra.fr

1 INRA, UMR1253 Science et Technologie du Lait et de l'CEuf, F-35042 Rennes, France

2 AGROCAMPUS OUEST, UMR1253 Science et Technologie du Lait et de l'CEuf, F-35042 Rennes, France 


\section{Introduction}

Microorganisms are key agents in the manufacture of fermented foods, where they generate a wide variety of flavours, textures, and appearances. Historically, milk fermentation was spontaneous and resulted from the presence of indigenous bacteria in milk and in the environment. Thanks to our increased knowledge of the fermentation process and of the bacterial groups involved in cheese manufacture, selected starters and ripening cultures are nowadays widely used to standardize the fermentation and reach the targeted properties for the final products. For this, bacterial species are chosen for their intrinsic species properties. For example, mesophilic or thermophilic species of lactic acid bacteria (LAB) are chosen according to their ability to acidify milk in the range of temperatures used in a given process. Likewise, some starter LAB species are chosen for their aromatizing or debittering properties, propionic acid bacteria (PAB) are used in Swiss-type cheeses to generate holes and specific flavour notes, and surface bacteria contribute to the characteristic flavour and colour of smear-rind cheeses. Many of these properties depend on the strain within a species, and the choice of a selected strain is thus a means to modulate the final cheese properties.

A bacterial species is defined on the basis of phenotypic properties and whole-genome DNA-DNA hybridization, which is a reference tool in microbial species delineation (Auch et al. 2010; Stackebrandt et al. 2002). In practice, the use of a polyphasic approach including an almost complete and high quality $16 \mathrm{~S}$ rRNA gene sequence combined with a robust phenotypic description is widely accepted for strain identification up to the species level (Stackebrandt et al. 2002). Within a bacterial species, a strain is defined as "the descendant of a single isolation in pure culture and usually made up of a succession of cultures ultimately derived from an initial single colony" (Staley and Krieg 1984). Although the strains of a given species share many phenotypical and genomic properties, they also exhibit some marked differences due to the genomic plasticity. Bacterial genomic plasticity is provided by two mechanisms: vertical transfer, which is related to the transfer of genetic information from one generation to the next, and horizontal gene transfer (HGT), which occurs between even non taxonomically related organisms of the same generation (Rossi et al. 2014; Cavanagh et al. 2015). It is largely responsible for bacterial adaptation (Ryall et al. 2012).

The adaptation to diverse ecological niches is genetically determined by the acquisition of new genes by HGT, in parallel to the decay and loss of non-essential genes as highlighted by comparative genomic analysis in LAB and PAB (Cai et al. 2009; Cavanagh et al. 2015; Kelleher et al. 2015; Loux et al. 2015; Papadimitriou et al. 2015). Many examples of HGT in food-related LAB species have been reported (Rossi et al. 2014). For example, the extracellular protease PrtS and the glutamic acid decarboxylase GadB in Streptococcus thermophilus have both been acquired by HGT (Rossi et al. 2014). Many technologically important traits are plasmid-encoded in Lactococcus lactis (Kelleher et al. 2015). Most dairy-associated isolates of L. lactis carry extensive plasmid complements, which can constitute up to $9 \%$ of the genetic material (Ainsworth et al. 2014). Transposable elements are commonly found in the chromosome and plasmids of L. lactis, and insertion sequences (IS) are involved in mutations resulting in gene activation or deactivation (Cavanagh et al. 2015). An extensive gene decay is observed in food-related LAB, resulting in up to $10 \%$ of pseudogenes in the genome (Papadimitriou et al. 2015). 
The intensive selection of LAB on properties for their dairy industrial use led to an increased specialization of so-called "domesticated" strains with an exacerbation of the targeted quality, such as fast acidification and a concomitant loss of other useless characteristics, compared to the "wild-type" ancestral strains. For example, the traditional division into dairy strains and non-dairy strains of L. lactis has recently been replaced by a new classification that distinguishes ecotypes corresponding to "domesticated" and "environmental" strains (Passerini et al. 2010). In Lactobacillus rhamnosus, the integration of genomic and phenotypic data of 100 strains isolated from various ecological niches revealed the presence of two prevailing geno-phenotypes, characterized by traits explaining their adaptation to dairy-like environments or to the intestinal tract, respectively (Douillard et al. 2013). Some pheno-genomic markers, such as carbohydrate metabolism, were proposed to characterize the ecology of L. rhamnosus strains. All the strains domesticated to the dairy environment share common properties, but they can also differ in the phenotypic traits of importance for their use in the dairy industry due, for example, to point gene mutations.

This review illustrates how the strain-dependent phenotypic variability can deeply impact the final properties of cheeses. This paper will preferably report on the results of studies that have demonstrated the impact of strains in situ in cheeses or in other dairy products including those in model dairy systems, when available, rather than in classical laboratory media. The mechanisms that explain the observed differences will also be presented whenever they are known. This paper provides some examples illustrating the extent of variations in the final properties of cheeses (e.g. organoleptic, techno-functional, safety, and health properties) that can result from the choice of selected strains within a LAB or PAB species.

\section{Technological properties}

This section gives examples of the strain-dependency of activities in LAB and PAB species that generate various metabolites involved in the formation of cheese flavour, texture, and techno-functional properties.

\subsection{Flavour properties}

The formation of flavour results from the conversion of milk lactose, citrate, caseins and lipids into taste and aroma compounds during the fermentation of dairy products. This section, through three examples, illustrates how the strain-to-strain variations in $\mathrm{LAB}$ and PAB species can strongly impact the formation of important flavour compounds in cheese. Some of the examples cited below are further detailed in Tables 1 and 2 illustrating the results of screening studies of LAB (Table 1) and PAB (Table 2).

\subsubsection{Formation of flavour compounds by L. lactis}

"Wild" strains of L. lactis produce a larger number of compounds in comparison to industrial dairy strains and may generate an unusual flavour, either desirable or undesirable (Alemayehu et al. 2014; Ayad et al. 1999; Cavanagh et al. 2014; Cavanagh et al. 2015). 
Many flavour compounds in cheese results from amino acid catabolism by LAB, generating a range of flavour notes in cheese (Yvon and Rijnen 2001). The amino acidconverting ability of LAB varies greatly from strain to strain (Smit et al. 2005). Two thirds of the wild strains of L. lactis grown in milk produced an unusual flavour compared to those produced by the industrial reference strains (Ayad et al. 1999). Tested in Gouda cheese manufacture in association with a reference industrial starter strain, some selected strains generated varied flavour notes, such as malty/chocolate, fruity and $\mathrm{H}_{2} \mathrm{~S}$ (Table 1). Some "wild" non-dairy strains of L. lactis have been shown to produce glutamate dehydrogenase (GDH), an enzyme that converts glutamate to $\alpha$ ketogluturate, thus enhancing the first rate-limiting reaction of the amino acid conversion to flavour compounds, an aminotransferase reaction, which requires an amino group acceptor such as $\alpha$-ketoglutarate (Tanous et al. 2002).

Lactococcus lactis subsp. lactis biovar diacetylactis strains are used in the dairy industry for generating acetoin and notably diacetyl, which imparts a buttery flavour note (Curioni and Bosset 2002). An elegant study recently highlighted the large straindependency in the production of acetoin and diacetyl in a collection of 35 L. lactis strains from diverse origins (Passerini et al. 2013). Dairy domesticated strains of the biovar diacetylactis harbour a citP plasmid gene encoding citrate permease and a chromosomal region citM-citI-citCDEFXG involved in citrate metabolism. These strains produce diacetyl or acetoin at a high level during early growth. Two out of the 11 environmental strains tested also produced a significant amount of these aroma compounds, although they do not use citrate (Passerini et al. 2013). In these strains, pyruvate flux was rerouted through the acetoin-diacetyl pathway and resulted in a production at a lower rate compared to citrate positive strains. Ten out of the 11 environmental strains were citrate-negative but produced acetoin or diacetyl through this pathway, in a highly strain-dependent manner, with final aroma concentrations varying from 2 to $20 \mathrm{mM}$ (Passerini et al. 2013). In another study, the 15 L. lactis strains tested produced different profiles of flavour compounds in fermented milk, with a clear distinction between the 3 dairy strains and 12 plant-derived strains. For example, the production of diacetyl and acetoin varied by a factor $>20$ and 200, respectively (Alemayehu et al. 2014). Differences between the amounts of acetoin produced by wild strains of L. lactis were also observed in miniature Chihuahua-type cheese (NájeraDomínguez et al. 2014).

\subsubsection{Hydrolysis of caseins by LAB: a complex proteolytic and lytic system implied in the formation of sapid peptides}

Proteolysis is a complex series of reactions which hydrolyses caseins, the main milk proteins, into peptides and free amino acids. It involves proteinases and peptidases from different origins: milk, coagulants added during process and microorganisms. The production of peptides by LAB cell envelope proteinases (CEP) is highly variable, both quantitatively and qualitatively, but gives fingerprints of overall proteolysis that are distinguishable among the various dairy fermented products. The size of peptides produced from casein hydrolysis ranges from 3 to more than 45 amino acid residues, due to the very broad specificity of the proteinases on caseins.

Either a unique or multiple CEP is present in LAB, depending on the species. For example, a unique CEP, PrtP, is present in L. lactis (Monnet et al. 1987), PrtS in 
S. thermophilus (Fernandez-Espla et al. 2000), PrtB in Lactobacillus delbrueckii (Laloi et al. 1991), and PrtR in L. rhamnosus (Pastar et al. 2003), whereas up to four CEPs are present in Lactobacillus helveticus, referred to as PrtH to PrtH4 (Broadbent et al. 2011; Sadat-Mekmene et al. 2011b). Moreover, the activity and specificity of CEP can also vary within a given species. For example, the PrtP proteases of the two strains of L. lactis subsp. cremoris WG2 and SK11 possess distinct specificities towards the peptide $\alpha$ s1-casein (f1-23) and were classified as type PI and PIII, respectively (Exterkate 1990; Exterkate and Alting 1995). The PrtP of L. lactis subsp. lactis NCDO 763 was classified as intermediate type PI/PIII (Monnet et al. 1992). The strain-dependency of casein hydrolysis is still higher within the L. helveticus species. The specificity of cleavage of $\beta$ - or $\alpha_{\mathrm{s} 1}$-caseins varies from strain to strain and also depends on the substrate (purified caseins or casein micelles in milk) (Sadat-Mekmene et al. 2011b). The 15 strains studied in vitro rapidly hydrolysed pure $\beta$-casein, but differed in the hydrolysis kinetics of $\alpha_{\mathrm{s} 1}$-casein, depending on their number of CEPs (Sadat-Mekmene et al. 2011a). Moreover, in cheese, the degree of proteolysis differed by a factor of 1.5 in Emmental cheeses manufactured using either L. helveticus ITGLH77 with only PrtH2 and a low level of lysis, or L. helveticus ITGLH1 having at least PrtH and PrtH2 encoding genes and a high lytic activity (Sadat-Mekmene et al.

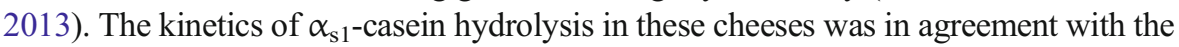
results observed in vitro.

As a consequence of CEP diversity, the peptide profile is highly dependent on the LAB species used as a starter. Some of the numerous peptides produced, rich in hydrophobic amino acid residues, confer bitterness to dairy products and notably in cheese, depending on their size, sequence and amount (Lemieux and Simard 1992; McSweeney 1997; Vassal and Gripon 1984). Proteolysis is a continuous process, and these hydrophobic bitter peptides can be further hydrolysed by bacterial intracellular peptidases released in cheese through LAB autolysis. The smaller peptides and free amino acids produced are associated with other taste compounds (sour, sweet, acid, brothy) and are precursors of flavour compounds (Yvon and Rijnen 2001). These peptidases are active throughout the ripening time in cheese, as shown in different cheeses (Emmental, Gagnaire et al. 1998; Valence et al. 2000, Cheddar, Sheehan et al. 2006, and semi-hard cheese, Boutrou et al. 1998). In semi-hard cheese manufactured using with five single strains of $L$. lactis with different lytic and proteolytic properties, good flavour scores and in particular non-bitter cheeses were only obtained with the strains both lytic and with a high proteolytic potential (Boutrou et al. 1998). It should be underlined that testing the in vitro proteolytic potential of LAB gives only a partial view of what can be expressed in situ in cheese. For example, the proteolytic potential of starter strains measured in vitro for cell-free extracts was not found to be correlated with the activity released in Cheddar cheese (Sheehan et al. 2006). The impact of straindependency due to the differences in L. lactis CEPs was shown in 50\% reduced-fat Cheddar cheese manufactured using isogenic single strains of L. lactis that had CEP with different substrate specificities and a CEP-negative strain (Broadbent et al. 2002). Cheeses made with the CEP-negative strain did not develop bitterness, whereas the other cheeses developed slight to moderate bitterness depending on CEP specificity (Broadbent et al. 2002). This could be related to the starter peptidase activity that could be reinforced in a CEP-negative strain (Farkye et al. 1990) compared to a CEP-positive strain. Therefore, the higher production in CEP-negative strains in Cheddar cheese of 


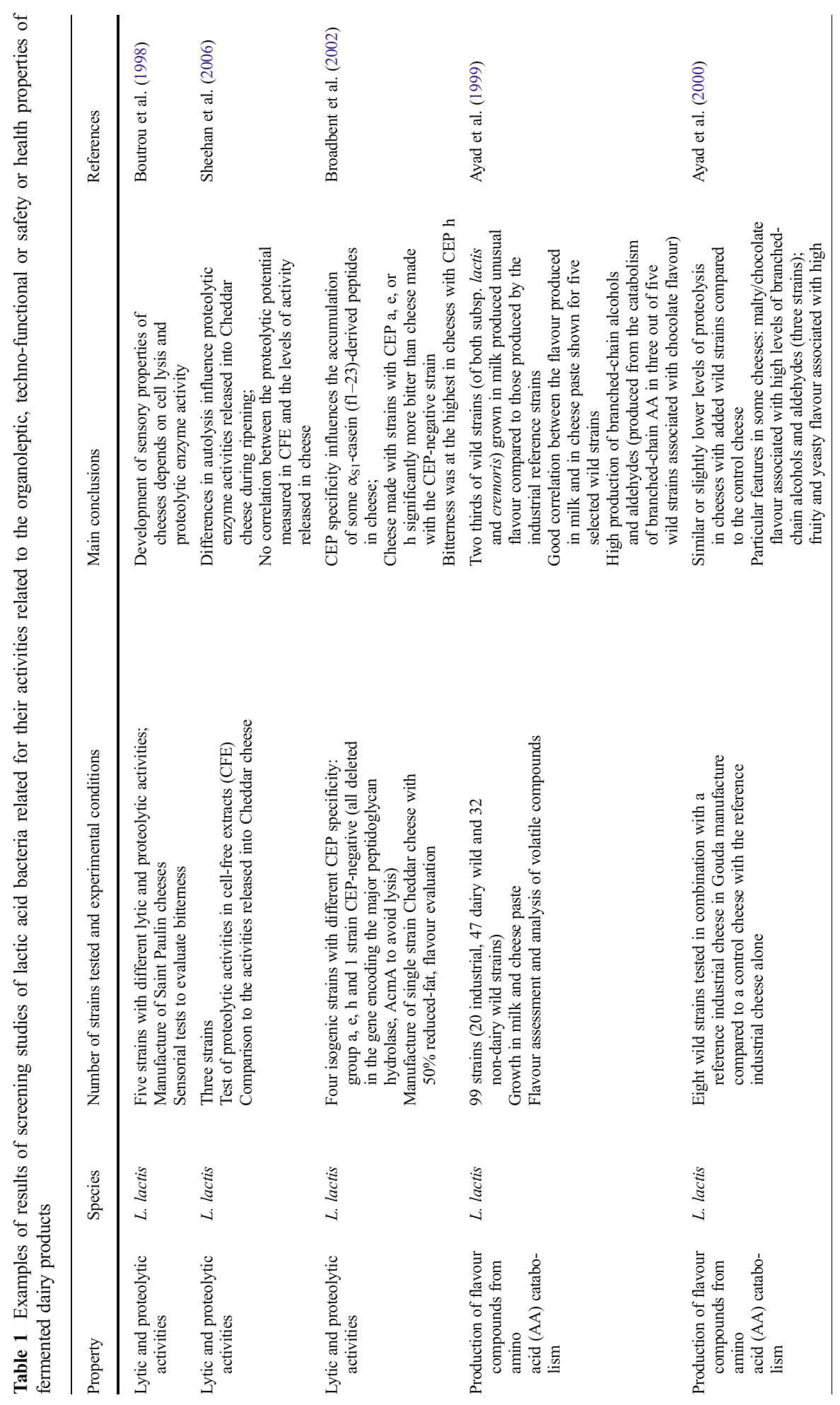

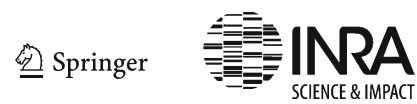




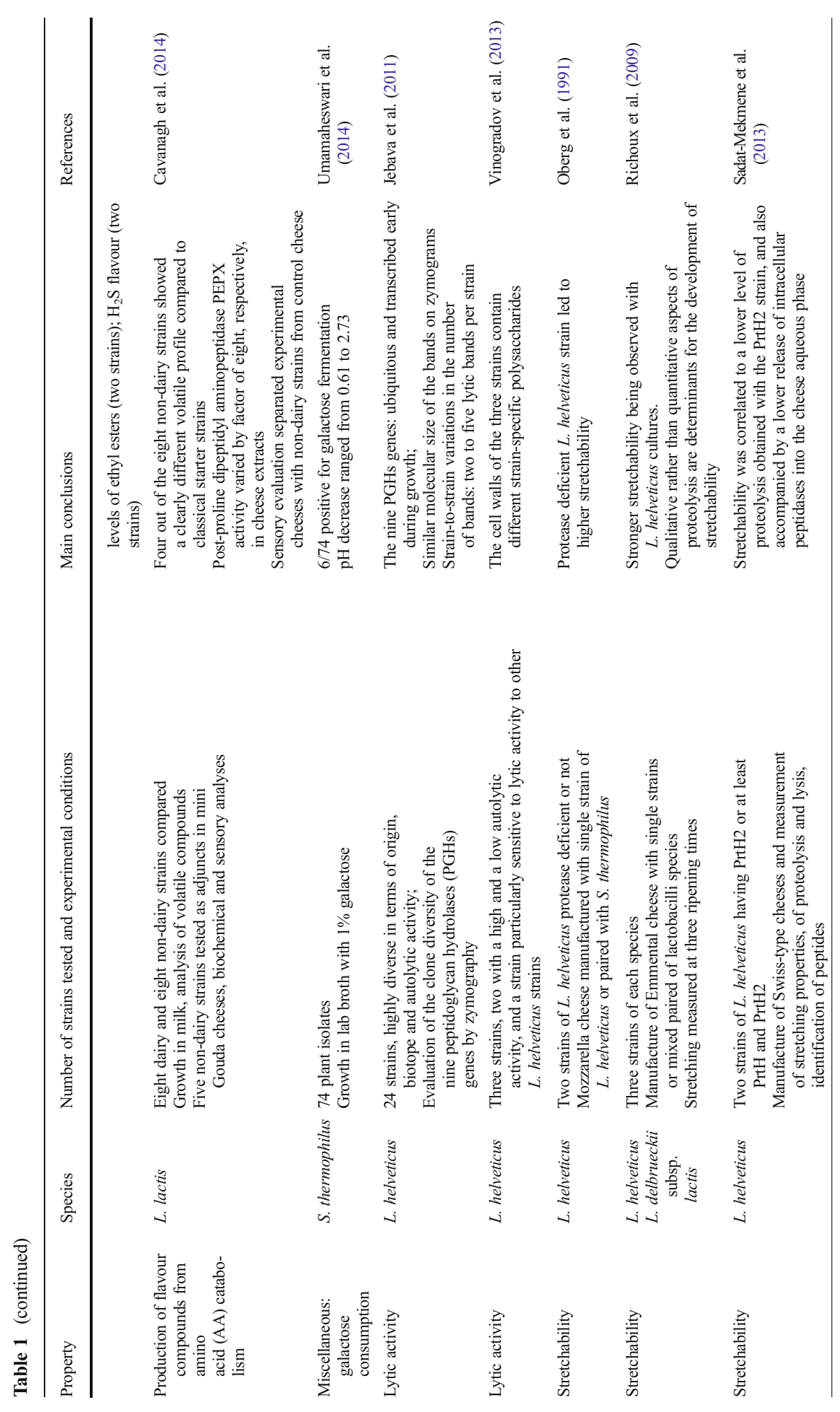




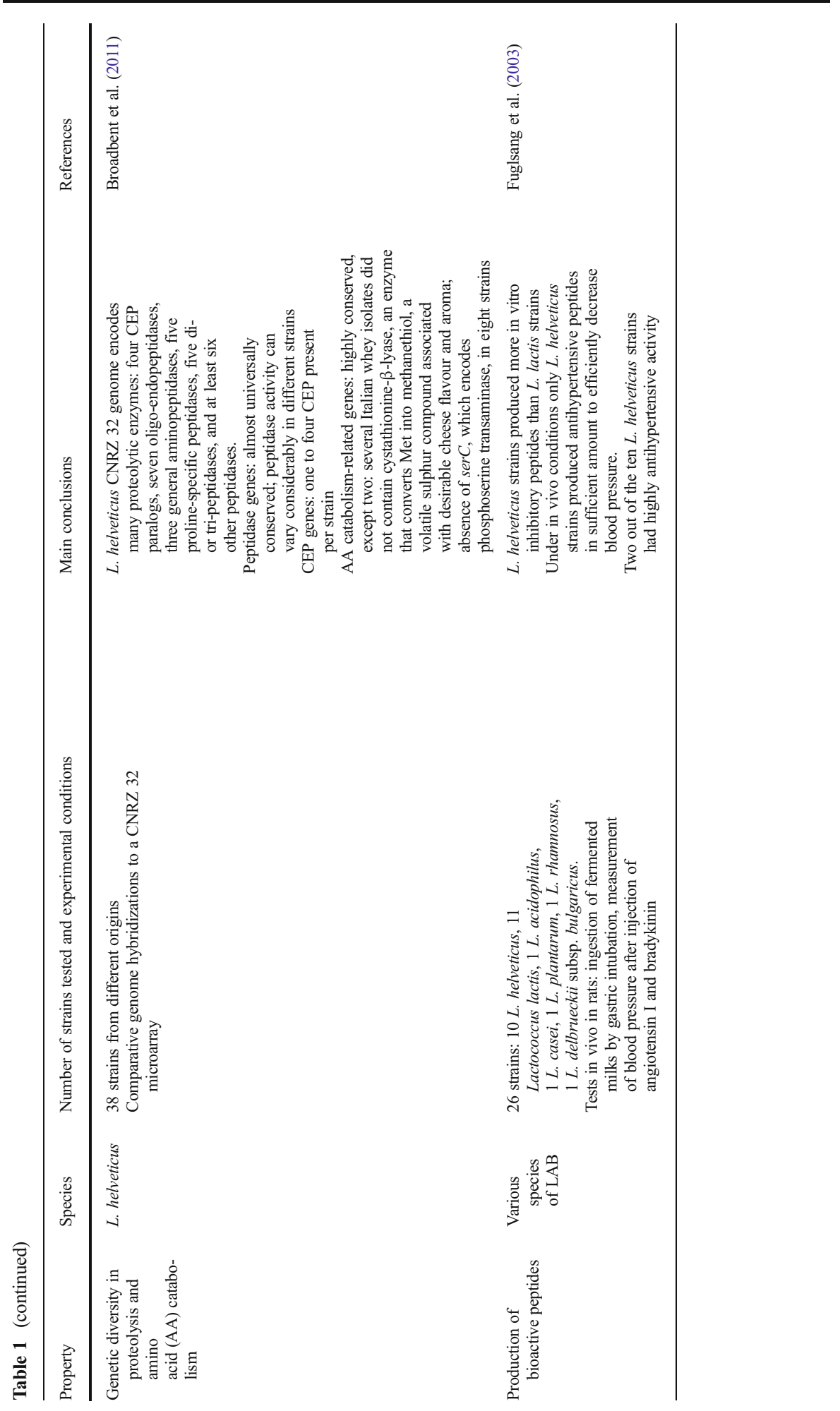

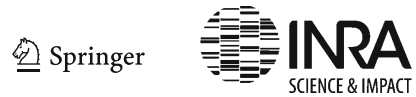







small peptides and amino acids that are precursor of in flavour compounds in cheese during ripening could have explained the different development of flavour in both types of strains having or not having CEP.

Bacterial lysis mainly concerns the LAB species used as starters, such as L. lactis, S. thermophilus, L. helveticus, and L. delbrueckii and, to a lesser extent, non-starter lactobacilli, such as Lactobacillus casei, Lactobacillus paracasei and Lactobacillus plantarum, and PAB. The molecular mechanisms responsible for different abilities to lyse are diverse and not all elucidated. Lysis results from the activity of peptidoglycan hydrolases (PGH) on the bacterial cell wall. It can also result from the induction of a prophage in L. lactis and L. helveticus but this is not a general mechanism (Lortal and Chapot-Chartier 2005; Deutsch et al. 2002, 2003). In L. helveticus, which exhibits a large range of autolytic abilities (Valence et al. 1998), the nine PGH genes are ubiquitous and transcribed early during growth in all the strains (Jebava et al. 2011). The differences of autolytic properties of strains would result from differences in cell wall composition (Vinogradov et al. 2013) (see Table 1 for further details).

\subsubsection{Formation of flavour compounds by propionibacteria}

Propionibacterium freudenreichii is used in the manufacture of Swiss-type cheeses, in which it is responsible for the formation of the typical flavour. It grows during the ripening, with lactic acid as the main carbon source, which is converted into propionic acid, acetic acid and $\mathrm{CO}_{2}$, responsible for hole formation (Fröhlich-Wyder and Bachmann 2004; Langsrud and Reinbold 1973). This ability is present in all propionibacteria strains. However, their growth and fermentation rates in cheese depend on the conditions, in particular, the $\mathrm{NaCl}$ content of the cheese (Richoux et al. 1998).

P. freudenreichii produces flavour compounds in cheese from three main pathways: lactate fermentation, amino acid catabolism, and fat hydrolysis (Thierry et al. 2011a). Regarding amino acid catabolism, $P$. freudenreichii mainly produces branched-chain (BC) volatile fatty acids from BC precursors. These BC volatile fatty acids are flavouractive compounds in many cheeses where they bring typical flavour notes of old cheese (Urbach 1997; Yvon and Rijnen 2001). Since the biosynthesis of BC volatile fatty acids is closely related to that of membrane fatty acids, this activity is constitutive and observed in all strains. However, the amounts of $\mathrm{BC}$ volatile fatty acids produced are highly strain-dependent. For example, the concentrations of $\mathrm{BC}$ volatile fatty acids ranged from 6 to over $50 \mathrm{mg} \cdot \mathrm{mL}^{-1}$ in the cultures of 40 strains of $P$. freudenreichii grown in cheese-like conditions (Dherbécourt et al. 2008). They ranged from 19 to $114 \mathrm{mg} \cdot \mathrm{kg}^{-1}$ at the end of ripening in eight experimental Swiss cheese manufactured using a single strain culture of $P$. freudenreichii (Thierry et al. 2004a). The formation of many other amino acid-derived aroma compounds varied significantly depending on the PAB strain, in P. freudenreichii as well as in the three other dairy PAB species (Yee et al. 2014). The ability to produce aroma compounds was not correlated with the subspecies of $P$. freudenreichii (De Freitas et al. 2015). The mechanism responsible for this strain-dependency is still unknown.

Fat hydrolysis during cheese ripening is another important aspect for flavour formation, because the free fatty acids (FFA) released are important flavour compounds in most cheeses. In Swiss-type cheeses, P. freudenreichii is the main agent of lipolysis 
(Chamba and Perreard 2002; Dherbécourt et al. 2010). However, the intensity of lipolytic activity of $P$. freudenreichii, again, is highly strain-dependent. In experimental Swiss cheeses manufactured using five different strains of $P$. freudenreichii, the net increases in FFA concentrations ranged from 0.2 to $3-4 \mathrm{mg} \cdot \mathrm{g}^{-1}$ cheese, compared to the control cheeses manufactured without propionibacteria (Chamba and Perreard 2002; Dherbécourt et al. 2010; Thierry et al. 2005). In a model medium supplemented with an emulsion of milk fat, 19 strains out of the 21 tested strains released FFA, with a net production of FFA ranging from 0.137 to $1915 \mathrm{mg} \cdot \mathrm{g}^{-1}$, whereas two strains did not display any detectable lipolytic activity (Abeijon Mukdsi et al. 2014). Interestingly, the intensities of lipolysis by $P$. freudenreichii were similar in this model medium and in cheese. In both non-lipolytic strains, the lipase gene responsible for lipolysis possesses a non-sense mutation leading to non-functional enzyme (Abeijon Mukdsi et al. 2014).

\subsection{Texture and exopolysaccharide production}

The production of exopolysaccharide (EPS) within LAB has been widely studied as a way to improve the texture of dairy products, such as low fat cheeses, and to reduce syneresis in fermented milks. The relationships between the amount and molecular characteristics of EPS and their functionality in the dairy products remain difficult to establish. However it clearly appears that the strain has a great impact on the final characteristic of the dairy products, since the production of EPS differs from strain to strain. Hence, some strains do not produce EPS, while other strains within the same species produce different molecules.

In fermented milks, it has been demonstrated that a reduced syneresis can be obtained by a discerning choice of the LAB strains implemented. Five EPS-producing or non-EPSproducing LAB (S. thermophilus, L. delbrueckii subsp. bulgaricus and L. lactis) were studied by Purohit et al. (2009). All the EPS-producing strains reduced the syneresis of fermented milks, whereas only some of these strains reduced the syneresis after cutting the products, indicating that the effectiveness of EPS-producing cultures depends on the type of EPS produced.

Fermented milks manufactured using 28 EPS-producing strains of Lactobacillus (14 L. plantarum strains, 9 L. kefiranofaciens strains and 5 L. paracasei strains) differed in their rheological properties (Hamet et al. 2015). The analysis of the EPS produced highlighted large variations between strains in terms of concentration and molecular weight of the molecules produced.

The relationship between the EPS structure and its function in situ has been investigated. The rheological properties of fermented milks made with strains of LAB producing EPS with known properties of charge, flexibility and degree of branching were affected. This indicates that the rheological properties of dairy products are affected by the structural characteristic of the molecules, especially the anionic charges (Gentès et al. 2011). These examples highlight that, with a careful selection of the strain, it is possible to improve the rheological and textural characteristics of dairy products.

\subsection{Opening and gas formation}

Propionibacterium freudenreichii has a key role in the formation of the typical round holes (eyes) in Swiss-type cheeses. The correct formation of holes depends on physicochemical factors, such as the presence of nucleation sites for hole development, an 
appropriate cheese structure, a massive production of carbon dioxide $\left(\mathrm{CO}_{2}\right)$ that induces a local saturation of gas leading to the formation of holes. During the ripening in the warm room, $P$. freudenreichii produces $\mathrm{CO}_{2}$ from lactate fermentation, thus producing the main part of the $\mathrm{CO}_{2}$ formed in cheese, the remaining part being formed by facultative heterofermentative lactobacilli from citrate fermentation and amino acid catabolism (Thierry et al. 2010).

Some $P$. freudenreichii strains express an aspartase activity, responsible for aspartate deamination. These strains co-ferment lactate and aspartate into propionate, acetate, succinate and $\mathrm{CO}_{2}$, which result in a higher ratio of $\mathrm{CO}_{2}$ produced per mole of fermented lactate (Wyder et al. 2001; Fröhlich-Wyder and Bachmann 2004). The screening of aspartase activity of $P$. freudenreichii strains isolated from cheese showed a very large strain-dependency (Table 2). The activity of cell-free extracts of eight wild strains of $P$. freudenreichii was shown to vary by a factor $>200$. In another study, half of the 100 strains tested exhibited $<100$ units (quantity of enzyme producing $0.01 \mathrm{nmol}$ of $\mathrm{NH}_{3} \cdot \mathrm{min}^{-1} \cdot \mathrm{mg}^{-1}$ of protein), while the activity of the other strains ranged from $<150$ to $>1500$ units (Blasco et al. 2011). The molecular bases of these strain-to-strain variations have not been investigated. Emmental cheeses manufactured using two multi-strain PAB cultures with high and low aspartase activity, respectively, were compared (Wyder et al. 2001). The PAB cultures with a high aspartate activity generated cheeses with no residual aspartate and aspargine, a higher content in succinate $(\times 3)$, and a greater number and size of holes. These types of strains induced an accelerated ripening of cheese, but also an increased risk of late fermentation associated with "split defect" in Swiss-type cheeses (Daly et al. 2010; Fröhlich-Wyder and Bachmann 2004).

\subsection{Techno-functional properties}

\subsubsection{Stretchability}

Some techno-functional properties of cheese, such as stretching after the culinary preparation of Mozzarella or Swiss-type cheese is related to proteolysis.

In the case of Mozzarella cheeses, LAB starters are $S$. thermophilus and L. helveticus or L. delbrueckii subsp. bulgaricus. Oberg et al. (1991) used two strains of L. helveticus highly $\left(\mathrm{Prt}^{+}\right)$or weakly (Prt ${ }^{-}$) proteolytic as a single starter strain or in combination with $S$. thermophilus and evaluated the consequences on stretching, melting and browning. Melting properties did not significantly differ depending on the starters used (Oberg et al. 1991). In contrast, stretching properties were higher in cheeses made with $L$. helveticus Prt $^{-}$strain, compared to the $\mathrm{Prt}^{+}$strain.

In Emmental cheese, Richoux et al. (2009) compared the stretchability of three strains of $L$. helveticus or L. delbrueckii subsp. lactis. Cheeses were manufactured with a single strain of $L$. helveticus or $L$. delbrueckii subsp. lactis, or a combination of one strain of each species. Only the cheeses manufactured with L. helveticus were able to make long strands (>350 mm). In cheeses manufactured with L. delbrueckii subsp. lactis alone or in combination with L. helveticus, the ability to stretch was at least decreased by a factor of two. It was not correlated to the total amount of peptides but to a balance between hydrophobic and hydrophilic peptides (Richoux et al. 2009). The relation with the number and/or activities of $L$. helveticus CEP and the ability of strains to lyse and to release their intracellular peptidases was a determinant in the 
stretchability, and differences in strand length between strains of more than $100 \mathrm{~mm}$ were observed (Sadat-Mekmene et al. 2013). Such a difference was correlated with a peculiar type of peptides, i.e. hydrophobic ones and with a size over 20 amino acid residues (Sadat-Mekmene et al. 2013).

\subsubsection{Cheese quality and galactose catabolism}

Galactose accumulation in cheese can favour the growth and $\mathrm{CO}_{2}$ production by undesirable non-starter bacteria capable of galactose utilization (Wu et al. 2015). It can also induce the browning of Mozzarella cheese (Johnson and Olson 1985). LAB such as L. delbrueckii subsp. bulgaricus and most S. thermophilus strains are unable to metabolize galactose (Gal-), whereas L. helveticus strains are Gal+. Gal- strains release in the medium or cheese the galactose moiety after cleavage of lactose by a $\beta$-galactosidase. However, some $S$. thermophilus strains able to catabolise galactose have been identified. The use of both Gal+ strains of Streptococcus spp. in combination with $L$. helveticus strains in the starter culture was probably responsible for the low residual galactose in Mozzarella cheese (Mukhurjee and Hutkins 1994). Gal+ strains of $S$. thermophilus were also utilized to reduce the quantity of residual galactose in yogurt (Umamaheswari et al. 2014). A yogurt prepared using a Gal+ S. thermophilus strain (NCDC 659) associated with L. delbrueckii subsp. bulgaricus contained $0.37 \%$ galactose compared to $0.98 \%$ in a reference yogurt inoculated with a Gal- $S$. thermophilus strain (Anbukkarasi et al. 2014). Galactose catabolism by LAB mainly relies on chromosome located-genes encoding the tagatose-6P and/or Leloir pathways (Wu et al. 2015), but the genetic basis for strain-dependency of this trait is still unclear.

\section{Functional properties}

In this section, we will consider the strain-dependency of functional properties of LAB and $\mathrm{PAB}$, considering the inhibition of deleterious microorganisms, with the example of bacteriocin production by $\mathrm{PAB}$, the inhibition of pathogenic bacteria, through the production of inhibitory compounds, the inhibition of virulence expression through the perturbation of quorum sensing systems and the probiotic effect regarding the immunomodulation related to surface proteins of PAB and antihypertensive peptides.

\subsection{Inhibition of spoilage and pathogenic microorganism growth}

Beyond their direct implication in the fermentation process of fermented dairy products, $\mathrm{LAB}$ and PAB are also used for their protective potential against spoilage and pathogenic microorganisms. Although this inhibitory potential is one important criterion for the selection of $\mathrm{LAB}$ and $\mathrm{PAB}$ starters, only a few studies addressed the intraspecific variations in the inhibitory potential. In a study on the antibacterial activity of L. plantarum, 347 food-derived isolates were tested against five foodborne pathogens. About $3-6 \%$ of isolates exerted a high antibacterial activity against at least one indicator bacterium ( $\mathrm{Li}$ et al. 2015). The effect was observed for seven out of the nine selected L. plantarum strains tested in fermented milk co-inoculated with a commercial yogurt starter ( $\mathrm{Li}$ et al. 2015). In this section, we will consider the strain-dependency of 
such properties, considering the inhibition of deleterious microorganisms, with the example of fungi in milk products, the inhibition of pathogenic bacteria, through the production of inhibitory compounds, and the inhibition of virulence expression through the perturbation of quorum sensing systems. Each of these potentials can be associated with the ability of the strains to produce a given compound, such as bacteriocins, organic acids, hydrogen peroxide, or must be considered as the combinatorial effect of several factors.

\subsubsection{Bacteriocin production}

Bacteriocins are ribosomally encoded peptides or proteins produced by bacteria to limit or totally inhibit the growth of competitor bacteria that are most often phylogenetically closely related. LABs have been screened for bacteriocin production for decades and several bacteriocins were discovered in LAB originating from various ecosystems and foodstuffs. Production and potential utilization of LAB-produced bacteriocins were recently reviewed in detail (see Bali et al. 2014; Perez et al. 2014).

PAB strains also produce bacteriocins (reviewed by Jan et al. 2007; Thierry et al. 2011b), including three antimicrobial peptides that display some quite unique traits compared with bacteriocins from LAB, propionicin T1, protease-activated antimicrobial peptide (PAMP) and propionicin F (Faye et al. 2011). The propionicin T1 peptide is produced by some strains of Propionibacterium thoenii and Propionibacterium jensenii, and is bactericidal towards all tested species of propionibacteria except $P$. freudenreichii. The encoding gene ( $p c t A)$ is widely distributed within $P$. jensenii and $P$. thoenii (Faye et al. 2004). However, only 5 of 13 pctA-positive $P$ jensenii strains produced antimicrobial activity corresponding to propionicin T1. The PAMP antimicrobial peptide is secreted in large amounts as an inactive precursor pro-PAMP protein, which is converted into PAMP upon proteolytic processing. The Pro-PAMP protein is produced by most strains of $P$. jensenii and $P$. thoenii but their sensitivity to PAMP varies quite extensively (Faye et al. 2004). Propionicin F is a hydrophobic and negatively charged bacteriocin produced by $P$. freudenreichii. It displays an intraspecies bactericidal inhibition spectrum, killing only strains of $P$. freudenreichii (Brede et al. 2004).

\subsubsection{Organic acid production}

Organic acids have deleterious effects on many neutrophilic bacteria and can significantly reduce their growth and threaten their viability (Lund et al. 2014). The production of organic acids, and the resulting acidification, is a major parameter in the inhibitory potential of starter LAB. For instance, Staphylococcus aureus growth is completely stopped in milk acidified at $\mathrm{pH} 4.4-4.5$ by lactic acid (Charlier et al. 2008). Only a few studies investigated the strain-dependency of this potential. In a panel of 75 L. lactis strains, 93\% $(n=70)$ presented a strong inhibition against the growth of the Gram positive pathogen $S$. aureus in milk, whereas $7 \%(n=5)$ were poor inhibitors, demonstrating that the inhibitory potential among L. lactis strains was not homogenous (Charlier et al. 2008). These results contrast with previous studies, which concluded that such a potential was homogenous (Haines and Harmon 1973a, b). Of note, these studies were based on a smaller panel of strains $(n=5)$ and tested the inhibitory potential in laboratory conditions. 
PAB also produced organic acids. In addition to their main fermentation endproducts, propionic, acetic and succinic acids, they also produce other organic acids with antifungal activities, 2-pyrrolidone-5-carboxylic, 3-phenyllactic, and hydroxyphenyllactic acids (Thierry et al. 2011a).

\subsubsection{Other compounds and combination of several compounds}

Hydrogen peroxide $\left(\mathrm{H}_{2} \mathrm{O}_{2}\right)$ is often cited as one of the inhibitory molecules produced by LAB. The ability of LAB to produce $\mathrm{H}_{2} \mathrm{O}_{2}$ appears to be strain-dependent. Ito et al. (2003) evaluated the ability of $193 \mathrm{LAB}$ strains isolated from various food products to produce $\mathrm{H}_{2} \mathrm{O}_{2}$ and found strong variations between strains. The scarce studies on $\mathrm{H}_{2} \mathrm{O}_{2}$ production by LAB in a food context report the ability of LAB isolated from food products, including dairy products, to produce $\mathrm{H}_{2} \mathrm{O}_{2}$. However, $\mathrm{H}_{2} \mathrm{O}_{2}$ production assays are generally performed in laboratory conditions (Ito et al. 2003; Enitan et al. 2011) rather than in situ in dairy products, probably because of the difficulty to quantify this unstable metabolite.

$\mathrm{H}_{2} \mathrm{O}_{2}$ production by a Lactococcus garvieae strain was recently demonstrated in a cheese matrix and this was in part responsible for $S$. aureus growth inhibition (DelbesPaus et al. 2010).

Diacetyl is a volatile compound produced by some LAB. It was shown to have an inhibitory activity against foodborne pathogens (Jay 1982; Kang and Fung 1999). Combinations of diacetyl with other antimicrobials such as nisin, an L. lactis bacteriocin, have shown a synergistic antimicrobial effect against foodborne pathogens (O'Bryan et al. 2009; Lee and Jin 2008). Only citrate-utilizing LAB can produce diacetyl and, in L. lactis, the citrate permease gene is plasmid-encoded. Likewise, a nisin operon is transposon-borne and thus, is not present in all L. lactis strains. Both diacetyl and nisin production are thus highly strain-dependent in this species. Such a synergistic effect of diacetyl and reuterin, a bacteriocin produced by some Lactobacillus reuteri strains, was recently demonstrated against several foodborne pathogens (E. coli O157:H7, Listeria monocytogenes, and Salmonella enterica subsp. enterica serovar Enteritidis (Langa et al. 2014)).

\subsubsection{Phenomena related to competition for nutrients}

While the inhibitory properties of LAB are frequently related to the production of inhibitory molecules, the involvement of nutrient-related phenomena should also be considered. Screening of $75 \mathrm{~L}$. lactis strains revealed that strains exhibiting strong inhibitory properties, with regard to $S$. aureus growth in milk, included strains with both high and low acidifying properties, and a residual inhibition occurred when $\mathrm{pH}$ was regulated at neutral $\mathrm{pH}$ (Charlier et al. 2008). This remaining inhibition strongly depended on the medium used. Whether these nutrient-related phenomena were a direct nutritional competition or limitation, or an indirect inhibitory effect remains unknown.

\subsubsection{Antifungal properties}

The ability of LAB and PAB to exert antifungal activities is now well established. These properties are most of the time multifactorial and result from the production of 
different metabolites by bacteria, such as organic acids, $\mathrm{H}_{2} \mathrm{O}_{2}, \mathrm{CO}_{2}$, ethanol, and proteinaceous compounds (peptides, cyclic dipeptides) (Crowley et al. 2013; Dalié et al. 2010). The production of most of these compounds is strain-dependent as illustrated later in this section. L. plantarum is the LAB species that is the most documented for antifungal properties, as well as, to a lesser extent, other lactobacilli, e.g. L. brevis, L. casei, L. pentosus, L. reuteri, and species of the genus Pediococcus (Schnürer and Magnusson 2005). There is abundant literature on in vitro screening studies in order to find specific LAB strains with antifungal properties and even if the number of strains tested within a species is generally low, strain-dependency has been reported. Up to $75 \%$ of variation was observed, for example, between the five strains of L. casei tested for their potential to inhibit the growth of four spoilage moulds (CortésZavaleta et al. 2014). Both the level of the antifungal activity and the spectrum of the fungal targets inhibited varied from strain to strain in LAB and PAB species tested in dairy models (Valence and Mounier, unpublished results).

\subsection{Inhibition of virulence expression of pathogens by LAB strains}

From a regulatory point of view among foodborne pathogens, toxin-producers like $S$. aureus can be tolerated in some foodstuffs (e.g. in raw milk cheeses) as long as it does not exceed a population level favouring the production of toxins (Cretenet et al. 2011a). The latter may indeed remain active in the end product even though the producer strain has disappeared. Besides inhibiting the pathogen growth, controlling the toxin production can thus be of special interest. The example of $S$. aureus enterotoxin production is of particular interest in a food context. It was shown that, when co-cultured with $S$. aureus, L. lactis strains are able to inhibit virulence expression in various $S$. aureus strains. The phenomenon is observed in laboratory conditions and in a model cheese where both species can grow at high levels (Even et al. 2009; Cretenet et al. 2011b). It is now known that L. lactis presence dramatically inhibits the accessory gene regulator ( $a g r)$ system in $S$. aureus. This system tightly controls virulence expression in $S$. aureus and, notably, the expression of agr-dependent staphylococcal enterotoxins (SEs), such as SEC. This feature is of great interest to control SE, although some SEs like SEA, whose expression is agr-independent, do not respond to this inhibitory activity. The mechanism involved in the inhibition is multifactorial and involves both the acidification and reducing properties of L. lactis (Nouaille et al. 2014). Although the strain-dependency of this inhibitory activity has not been investigated in depth, one might consider that it is not highly strain-dependent. Indeed, when considered individually, the properties involved in the inhibition (reducing capacities and acidification) reportedly vary with the strains (Charlier et al. 2008; Charlier et al. 2009; Michelon et al. 2013), but they clearly overlap here in the virulence inhibition exerted by L. lactis. In this system, a low reducing capacity might likely be compensated by the acidification of the medium and thus might not result in a complete alleviation of the inhibition.

\subsection{Immunomodulation by dairy bacteria}

Some dairy-related bacterial species are "2-in-1" bacteria that can be involved in both the elaboration of fermented dairy products such as cheeses and in beneficial health (socalled probiotic) effects on the host. As an example, the most used PAB species, $P$. freudenreichii, was shown to display anti-inflammatory properties, in a very strain- 
dependent manner (Foligné et al. 2010). Out of a selection of 23 strains of $P$. freudenreichii, a continuum from strains having no immunomodulatory effect to strains with a very marked anti-inflammatory one was observed ex vivo on fresh human peripheral blood mononuclear cells (PBMCs) using Il-10 induction as a marker (Foligné et al. 2013). Accordingly, the strain inducing the highest level of IL-10 ex vivo protected mice from induced colitis in vivo, either consumed as a pure culture (Le Marechal et al. 2015) or as an experimental semi-hard cheese (Plé et al. 2015). In contrast, strains which failed to induce IL-10 ex vivo also failed to protect from colitis in vivo (Jan, unpublished results, ANR project ANR-2010-ALIA-016 “SURFING”). The surface compounds involved in this immunomodulation are strain-specific surface proteins of the S-layer-type (Le Marechal et al. 2015). By contrast, some $P$. freudenreichii strains produce a surface beta-glucan exopolysaccharide after growth in a dairy-based medium and display no immunomodulatory properties, while the mutational inactivation of this exopolysaccharide capsule leads to anti-inflammatory properties of the mutant strains (Deutsch et al. 2010, 2012). Accordingly, pure cultures of $P$. freudenreichii ET-3 in whey exerted protective effects in experimental colitis in mice (Okada et al. 2006; Uchida and Mogami 2005). A pilot clinical study on ulcerative colitis also suggests a beneficial effect of this strain in humans (Suzuki et al. 2006). The development of an experimental cheese, fermented by a selected antiinflammatory strain of $P$. freudenreichii exclusively, and protective against colitis, recently evidenced that the choice of the starter strain(s) determines the probiotic effect of the cheese (Plé et al. 2015).

Similar strain-dependent immunomodulation was also reported for lactic acid dairy starters including Lactobacillus debrueckii (Santos-Rocha et al. 2012), S. thermophilus (Del Carmen et al. 2015), and L. helveticus (Hosoya et al. 2014; Yamashita et al. 2014). A yogurt containing anti-inflammatory L. debrueckii and S. thermophilus accordingly exerted preventive effect in ulcerative colitis patients (Magee et al. 2005). Furthermore, cheese made with L. helveticus LH2171 alleviated symptoms of experimental colitis (Hosoya et al. 2012), while another strain MIMLh5 displayed pro-inflammatory properties (Taverniti et al. 2013).

\subsection{Production of antihypertensive peptides by lactic acid bacteria}

Peptides have numerous bioactivities and among them, antihypertensive activity has been more particularly studied in milk and cheeses according to strain-dependency. Thus, Fuglsang et al. (2003) showed that among the 10 strains of L. helveticus and 11 strains of $L$. lactis that have antihypertensive activity after milk fermentation, two strains of $L$. helveticus were able to decrease blood pressure in rats after feeding with fermented milk, in contrast to L. lactis strains. Another predominant action of L. helveticus and L. delbrueckii was also shown in Swiss-type cheeses, in which the levels and dynamics of the ACE inhibitory activity varied according to the combination of lactobacilli strains used, up to sixfold at the end of the ripening time (Gagnaire et al. 2012). Among the 18 combinations of starters strains used, only one containing one strain of L. helveticus and one of $L$. delbrueckii, both with a moderate proteolytic activity, led to a high ACE inhibitory activity. The latter was not predictable from the intensity of proteolysis observed, showing that the quality of the proteolysis prevails on the quantity of the peptide produced (Gagnaire et al. 2012). 
As a conclusion, the choice of dairy starters, taking into account their bioactive profile, may orientate a fermented food product towards probiotic effects, depending on the targeted specific population.

\section{Conclusions and perspectives}

This review illustrates how the choice of a bacterial strain within a given species can induce a great extent of differences for important properties of fermented dairy products. On one hand, and for some peculiar characteristics, the technological, probiotic, or inhibitory potential towards undesirable microorganisms of LAB or PAB is clearly strain-dependent, especially when it is based on the presence of a gene (or an operon) as it is for bacteriocin or diacetyl production. On the other hand, when the potential of interest relies on metabolic activities and overlapping properties (e.g. antifungal activity, inhibition of virulence expression in S. aureus by L. lactis), the strain-dependency may be lower, even though each of the features involved can be strain-dependent. However, only a few studies have tested large numbers of strains of the same species, preventing any definitive conclusion.

Some properties that were initially considered as constant features for a given species based on screening of a few strains can later appear to be highly variable and straindependent when a higher number of strains are investigated. Therefore, general conclusions on the compared properties of different species should not be drawn until a sufficient number of strains of each species are tested. The great impact of the intraspecific diversity on the final quality of fermented dairy products also stress the importance of an adequate preservation of microbial resources, which should be made accessible to the scientific community to facilitate their screening and valorisation. The Organization for Economic Cooperation and Development (OECD) has established the concept of Biological Resource Centre (BRC) and edited specific guidelines (OECD 2007). Microbial BRC, in particular, have been described as a factor in economic development (Smith et al. 2014). Microorganisms have both a patrimonial value and a potential for innovation. The larger the number of strains for a specific species, the greater the possibility of discovering strains with a specific potential for innovation. Interestingly, $79 \%$ of new microbial species described in 2009 are based on one unique strain, the type strain (Stackebrandt 2011). This underlines the role of food-related microbial BRCs, who continuously enlarge collections of microbial resources and are a major actor for innovation in the dairy industry. The concomitant development of high-through sequencing and screening facilities will help in linking phenotypic properties of interest with genomic and molecular features. Once established, these links will greatly enhance our understanding of strain-dependency as well as our screening procedures for the rational selection of $\mathrm{LAB}$ or $\mathrm{PAB}$ strains with a property of interest for the dairy industry.

\section{References}

Abeijon Mukdsi MC, Falentin H, Maillard MB, Chuat V, Medina RB, Parayre S, Thierry A (2014) The secreted esterase of Propionibacterium freudenreichii has a major role in cheese lipolysis. Appl Environ Microbiol 80:751-756 
Ainsworth S, Stockdale S, Bottacini F, Mahony J, van Sinderen D (2014) The Lactococcus lactis plasmidome: much learnt, yet still lots to discover. FEMS Microbiol Rev 38:1066-1088. doi:10.1111/1574-6976.12074

Alemayehu D, Hannon JA, McAuliffe O, Ross RP (2014) Characterization of plant-derived lactococci on the basis of their volatile compounds profile when grown in milk. Int J Food Microbiol 172:57-61. doi:10. 1016/j.ijfoodmicro.2013.11.024

Anbukkarasi K, UmaMaheswari T, Hemalatha T, Nanda DK, Singh P, Singh R (2014) Preparation of low galactose yogurt using cultures of Gal+ Streptococcus thermophilus in combination with Lactobacillus delbrueckii ssp. bulgaricus. J Food Sci Technol 51:2183-2189. doi:10.1007/s13197-014-1262-5

Auch AF, von Jan M, Klenk H-P, Göker M (2010) Digital DNA-DNA hybridization for microbial species delineation by means of genome-to-genome sequence comparison. Stand Genom Sci 2:117-134. doi:10. 4056/sigs.531120

Ayad EHE, Verheul A, De Jong C, Wouters JTM, Smit G (1999) Flavour forming abilities and amino acid requirements of Lactococcus lactis strains isolated from artisanal and non-dairy origin. Int Dairy J 9:725-735

Ayad EHE, Verheul A, Vouters JTM, Smit G (2000) Application of wild starter cultures for flavour development in pilot plant cheese making. Int Dairy J 10:169-179

Bali V, Panesar PS, Bera MB (2014) Trends in utilization of agro-industrial byproducts for production of bacteriocins and their biopreservative applications. Crit Rev Biotechnol. doi:10.3109/07388551.2014. 947916

Blasco L, Kahala M, Tupasela T, Joutsjoki V (2011) Determination of aspartase activity in dairy Propionibacterium strains: aspartase activity in dairy propionibacteria. FEMS Microbiol Lett 321:1013. doi:10.1111/j.1574-6968.2011.02299.x

Boutrou R, Sepulchre A, Pitel G, Durier C, Vassal L, Gripon JC, Monnet V (1998) Lactococcal lysis and curd proteolysis: two predictable events important for the development of cheese flavour. Int Dairy J 8:609616

Brede DA, Faye T, Johnsborg O, Odegard I, Nes IF, Holo H (2004) Molecular and genetic characterization of propionicin F, a bacteriocin from Propionibacterium freudenreichii. Appl Environ Microbiol 70:73037310

Broadbent JR, Barnes M, Brennand C, Strickland M, Houck K, Johnson M, Steele J (2002) Contribution of Lactococcus lactis cell envelope proteinase specificity to peptide accumulation and bitterness in reducedfat Cheddar cheese. Appl Environ Microbiol 68:1778-1785

Broadbent JR, Cai H, Larsen RL, Hughes JE, Welker DL, De Carvalho VG, Tompkins TA (2011) Genetic diversity in proteolytic enzymes and amino acid metabolism among Lactobacillus helveticus strains. J Dairy Sci 94:4313-4328

Cai H, Thompson R, Budinich MF, Broadbent JR, Steele JL (2009) Genome sequence and comparative genome analysis of Lactobacillus casei: insights into their niche-associated evolution. Genome Biol Evol 1:239-257

Cavanagh D, Kilcawley KN, O’Sullivan MG, Fitzgerald GF, McAuliffe O (2014) Assessment of wild nondairy lactococcal strains for flavour diversification in a mini-Gouda type cheese model. Food Res Int 62 : 432-440. doi:10.1016/j.foodres.2014.03.043

Cavanagh D, Fitzgerald GF, McAuliffe O (2015) From field to fermentation: the origins of Lactococcus lactis and its domestication to the dairy environment. Food Microbiol 47:45-61. doi:10.1016/j.fm.2014.11.001

Chamba JF, Perreard E (2002) Contribution of propionic acid bacteria to lipolysis of Emmental cheese. Lait $82: 33-44$

Charlier C, Even S, Gautier M, Le Loir Y (2008) Acidification is not involved in the early inhibition of Staphylococcus aureus growth by Lactococcus lactis in milk. Int Dairy J 18:197-203

Charlier C, Cretenet M, Even S, Le Loir Y (2009) Interactions between Staphylococcus aureus and lactic acid bacteria: an old story with new perspectives. Int J Food Microbiol 131:30-39

Cortés-Zavaleta O, López-Malo A, Hernández-Mendoza A, García HS (2014) Antifungal activity of lactobacilli and its relationship with 3-phenyllactic acid production. Int J Food Microbiol 173:30-35. doi:10.1016/j.ijfoodmicro.2013.12.016

Cretenet M, Even S, Le Loir Y (2011a) Unveiling Staphylococcus aureus enterotoxin production in dairy products: a review of recent advances to face new challenges. Dairy Sci Technol 91:127-150

Cretenet M, Nouaille S, Thouin J, Rault L, Stenz L, François P, Hennekinne JA, Piot M, Maillard MB, Fauquant J, Loubière P, Le Loir Y, Even S (2011b) Staphylococcus aureus virulence and metabolism are dramatically affected by Lactococcus lactis in cheese matrix. Environ Microbiol Rep 3:340-351

Crowley S, Mahony J, van Sinderen D (2013) Current perspectives on antifungal lactic acid bacteria as natural bio-preservatives. Trends Food Sci Technol 33:93-109. doi:10.1016/j.tifs.2013.07.004

Curioni PMG, Bosset JO (2002) Key odorants in various cheese types as determined by gas chromatographyolfactometry. Int Dairy J 12:959-984

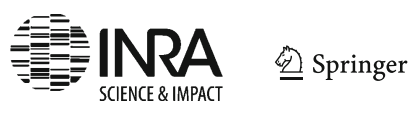


Dalié DKD, Deschamps AM, Richard-Forget F (2010) Lactic acid bacteria-potential for control of mould growth and mycotoxins: a review. Food Control 21:370-380. doi:10.1016/j.foodcont.2009.07.011

Daly DFM, McSweeney PLH, Sheehan JJ (2010) Split defect and secondary fermentation in Swiss-type cheeses-a review. Dairy Sci Technol 90:3-26

De Freitas R, Madec M-N, Chuat V, Maillard MB, Abeijon Mukdsi MC, Falentin H, de Carvalho AF, Valence F, Thierry A (2015) New insights about phenotypic heterogeneity within Propionibacterium freudenreichii argue against its division into subspecies. Dairy Sci Technol 95:465-477. doi:10.1007/ s13594-015-0229-2

Del Carmen S, Miyoshi A, Azevedo V, de de Moreno LA, LeBlanc JG (2015) Evaluation of a Streptococcus thermophilus strain with innate anti-inflammatory properties as a vehicle for IL-10 cDNA delivery in an acute colitis model. Cytokine 73:177-183

Delbes-Paus C, Dorchies G, Chaabna Z, Callon C, Montel MC (2010) Contribution of hydrogen peroxide to the inhibition of Staphylococcus aureus by Lactococcus garvieae in interaction with raw milk microbial community. Food Microbiol 27:924-932

Deutsch SM, Ferain T, Delcour J, Lortal S (2002) Lysis of lysogenic strains of Lactobacillus helveticus in Swiss cheeses and first evidence of concomitant Streptococcus thermophilus lysis. Int Dairy J 12:591600

Deutsch SM, Neveu A, Guezenec S, Ritzenthaler P, Lortal S (2003) Early lysis of Lactobacillus helveticus CNRZ 303 in Swiss cheese is not prophage-related. Int J Food Microbiol 81:147-157

Deutsch SM, Le Bivic P, Herve C, Madec MN, LaPointe G, Jan G, Le Loir Y, Falentin H (2010) Correlation of the capsular phenotype in Propionibacterium freudenreichii with the level of expression of gtf, a unique polysaccharide synthase-encoding gene. Appl Environ Microbiol 76:2740-2746

Deutsch SM, Parayre S, Bouchoux A, Guyomarc'h F, Dewulf J, Dols-Lafargue M, Baglinière F, Cousin FJ, Falentin H, Jan G, Foligné B (2012) Contribution of surface beta-glucan polysaccharide to physicochemical and immunomodulatory properties of Propionibacterium freudenreichii. Appl Environ Microbiol 78: 1765-1775

Dherbécourt J, Maillard MB, Catheline D, Thierry A (2008) Production of branched-chain aroma compounds by Propionibacterium freudenreichii: links with the biosynthesis of membrane fatty acids. J Appl Microbiol 105:977-985

Dherbécourt J, Bourlieu C, Maillard MB, Aubert-Frogerais L, Richoux R, Thierry A (2010) Time course and specificity of lipolysis in Swiss cheese. J Agric Food Chem 58:11732-11739

Douillard FP, Ribbera A, Kant R, Pietila TE, Jarvinen HM, Messing M, Randazzo CL, Paulin L, Laine P, Ritari J (2013) Comparative genomic and functional analysis of 100 Lactobacillus rhamnosus strains and their comparison with strain GG. PLoS Genet 9:e1003683

Enitan A, Adeyemo J, Ogunbanwo ST (2011) Influence of growth conditions and nutritional requirements on the production of hydrogen peroxide by lactic acid bacteria. Afr J Microbiol Res 5:2059-2066. doi:10. 5897/AJMR11.128

Even S, Charlier C, Nouaille S, Ben Zakour NL, Cretenet M, Cousin FJ, Gautier M, Cocaign-Bousquet M, Loubiere P, Le Loir Y (2009) Staphylococcus aureus virulence expression is impaired by Lactococcus lactis in mixed cultures. Appl Environ Microbiol 75:4459-4472

Exterkate FA (1990) Differences in short peptides-substrate cleavage by two cell-envelope-located serine proteases of Lactococcus lactis subsp. cremoris are related to secondary binding specificity. Appl Microbiol Biotechnol 33:401-406

Exterkate FA, Alting AC (1995) The role of starter peptidases in the initial proteolytic events leading to amino acids in Gouda cheese. Int Dairy J 5:15-28

Farkye NY, Fox PF, Fitzgerald GF, Daly C (1990) Proteolysis and flavor development in Cheddar cheese made exclusively with single strain proteinase-positive or proteinase-negative starters. J Dairy Sci 73 : 874-880

Faye T, Brede DA, Langsrud T, Nes IF, Holo H (2004) Prevalence of the genes encoding propionicin T1 and protease-activated antimicrobial peptide and their expression in classical propionibacteria. Appl Environ Microbiol 70:2240-2244

Faye T, Holo H, Langsrud T, Nes IF, Brede DA (2011) The unconventional antimicrobial peptides of the classical propionibacteria. Appl Microbiol Biotechnol 89:549-554

Fernandez-Espla MD, Garault P, Monnet V, Rul F (2000) Streptococcus thermophilus cell wall-anchored proteinase: release, purification and biochemical and genetic characterization. Appl Environ Microbiol 66: 4772-4778

Foligné B, Deutsch SM, Breton J, Cousin FJ, Dewulf J, Samson M, Pot B, Jan G (2010) Promising immunomodulatory effects of selected strains of dairy propionibacteria as evidenced in vitro and in vivo. Appl Environ Microbiol 76:8259-8264 
Foligné B, Breton J, Mate D, Jan G (2013) Tracking the microbiome functionality: focus on Propionibacterium species. Gut 62:1227-1228

Fröhlich-Wyder MT, Bachmann HP (2004) In: Fox PF, McSweeney PLH, Cogan TM, Guinee TP (eds) Cheeses with propionic acid fermentation. Elsevier, London, pp 141-156

Fuglsang A, Rattray FP, Nilsson D, Nyborg NC (2003) Lactic acid bacteria: inhibition of angiotensin converting enzyme in vitro and in vivo. A Van Leeuw J Microb 83:27-34

Gagnaire V, Lortal S, Léonil J (1998) Free active peptidases are detected in Emmental juice extracted before ripening in the warm room. J Dairy Res 65:119-128

Gagnaire V, Lortal S, Berthier F, Buchin S (2012) Modulating the bioactive peptide content in Swiss cheeses by combination of thermophilic lactobacilli strains and species 26th IDF Cheese Ripening \& Technology Symposium, May 21-24 Madison, USA

Gentès M-C, St-Gelais D, Turgeon SL (2011) Gel formation and rheological properties of fermented milk with in situ exopolysaccharide production by lactic acid bacteria. Dairy Sci Technol 91:645-661. doi:10.1007/ s13594-011-0039-0

Haines WC, Harmon LG (1973a) Effect of selected lactic acid bacteria on growth of Staphylococcus aureus and production of enterotoxin. Appl Microbiol 25:436-441

Haines WC, Harmon LG (1973b) Effect of variations in conditions of incubation upon inhibition of Staphylococcus aureus by Pediococcus cerevisiae and Streptococcus lactis. Appl Microbiol 25:169-172

Hamet MF, Piermaria JA, Abraham AG (2015) Selection of EPS-producing Lactobacillus strains isolated from kefir grains and rheological characterization of the fermented milks. LWT-Food Sci Technol 63:129-135. doi:10.1016/j.lwt.2015.03.097

Hosoya T, Ogawa A, Sakai F, Kadooka Y (2012) A cheese-containing diet modulates immune responses and alleviates dextran sodium sulfate-induced colitis in mice. J Dairy Sci 95:2810-2818

Hosoya T, Sakai F, Yamashita M, Shiozaki T, Endo T, Ukibe K, Uenishi H, Kadooka Y, Moriya T, Nakagawa H, Nakayama Y, Miyazaki T (2014) Lactobacillus helveticus SBT2171 inhibits lymphocyte proliferation by regulation of the JNK signaling pathway. PLoS ONE 9:e108360

Ito A, Sato Y, Kudo S, Sato S, Nakajima H, Toba T (2003) The screening of hydrogen peroxide-producing lactic acid bacteria and their application to inactivating psychrotrophic food-borne pathogens. Current Microbiol 47:231-236. doi:10.1007/s00284-002-3993-1

Jan G, Lan A, Leverrier P (2007) Dairy propionibacteria as probiotics. In: Saarela M (ed) Functionnal dairy products. Woodhead Publishing Limited, CRC Press LLC, Cambridge, pp 165-194

Jay JM (1982) Antimicrobial properties of diacetyl. Appl Environ Microbiol 44:525-532

Jebava I, Plockova M, Lortal S, Valence F (2011) The nine peptidoglycan hydrolases genes in Lactobacillus helveticus are ubiquitous and early transcribed. Int J Food Microbiol 148:1-7. doi:10.1016/j.ijfoodmicro. 2011.04.015

Johnson ME, Olson NF (1985) Nonenzymatic browning of Mozzarella cheese. J Dairy Sci 68:3143-3147

Kang DH, Fung DY (1999) Effect of diacetyl on controlling Escherichia coli O157:H7 and Salmonella Typhimurium in the presence of starter culture in a laboratory medium and during meat fermentation. $\mathbf{J}$ Food Prot 62:975-979

Kelleher P, Murphy J, Mahony J, van Sinderen D (2015) Next-generation sequencing as an approach to dairy starter selection. Dairy Sci Technol 95:545-568. doi:10.1007/s13594-015-0227-4

Laloi P, Atlan D, Blanc B, Gilbert C, Portalier R (1991) Cell-wall-associated proteinase of Lactobacillus delbrueckii subsp. bulgaricus CNRZ 397: differential extraction; purification and properties of the enzyme. Appl Microbiol Biotechnol 36:196-204

Langa S, Martín-Cabrejas I, Montiel R, Landete JM, Medina M, Arqués JL (2014) Short communication: combined antimicrobial activity of reuterin and diacetyl against foodborne pathogens. J Dairy Sci 97: 6116-6121. doi:10.3168/jds.2014-8306

Langsrud T, Reinbold GW (1973) Flavor development and microbiology of Swiss cheese-a review. II. Starters, manufacturing processes and procedures. J Milk Food Technol 36:531-542

Le Marechal C, Peton V, Ple C, Vroland C, Jardin J, Briard-Bion V, Durant G, Chuat V, Loux V, Foligné B, Deutsch SM, Falentin H, Jan G (2015) Surface proteins of Propionibacterium freudenreichii are involved in its anti-inflammatory properties. J Proteom 113:447-461. doi:10.1016/j.jprot.2014.07.018

Lee S-Y, Jin H-H (2008) Inhibitory activity of natural antimicrobial compounds alone or in combination with nisin against Enterobacter sakazakii. Lett Appl Microbiol 47:315-321. doi:10.1111/j.1472-765X.2008.02432.x

Lemieux L, Simard RE (1992) Bitter flavour in dairy products. II. A review of bitter peptides from caseins: their formation; isolation and identification; structure masking and inhibition. Lait 72:335-3822

Li C, Chen Y, Kwok L-Y, Chen X, Yu H, Yang H, Yang J, Xue J, Sun T, Zhang H (2015) Identification of potential probiotic Lactobacillus plantarum isolates with broad-spectrum antibacterial activity. Dairy Sci Technol 95:381-392. doi:10.1007/s13594-014-0206-1

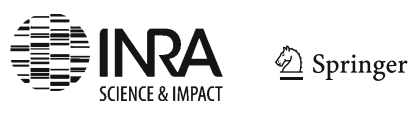


Lortal S, Chapot-Chartier MP (2005) Role, mechanisms and control of lactic acid bacteria lysis in cheese. Int Dairy J 15:857-871

Loux V, Mariadassou M, Almeida S, Chiapello H, Hammani A, Buratti J, Gendrault A, Barbe V, Aury J-M, Deutsch S-M, Parayre S, Madec M-N, Chuat V, Jan G, Peterlongo P, Azevedo V, Le Loir Y, Falentin H (2015) Mutations and genomic islands can explain the strain dependency of sugar utilization in 21 strains of Propionibacterium freudenreichii. BMC Genom. doi:10.1186/s12864-015-1467-7

Lund P, Tramonti A, De Biase D (2014) Coping with low pH: molecular strategies in neutralophilic bacteria. FEMS Microbiol Rev 38:1091-1125. doi:10.1111/1574-6976.12076

Magee EA, Edmond LM, Tasker SM, Kong SC, Curno R, Cummings JH (2005) Associations between diet and disease activity in ulcerative colitis patients using a novel method of data analysis. Nutr J 4:7

McSweeney PLH (1997) The flavour of milk and dairy products: II. Cheese: taste. Int J Dairy Technol 50: 123-128

Michelon D, Tachon S, Ebel B, De Coninck J, Feron G, Gervais P, Yvon M, Cachon R (2013) Screening of lactic acid bacteria for reducing power using a tetrazolium salt reduction method on milk agar. J Biosci Bioeng 115:229-232. doi:10.1016/j.jbiosc.2012.09.010

Monnet V, Le Bars D, Gripon JC (1987) Purification and characterization of a cell wall proteinase from Streptococcus lactis NCDO 763. J Dairy Res 54:247-255

Monnet V, Ley JP, Gonzales S (1992) Substrate specificity of the cell envelope-located proteinase of Lactococcus lactis subsp. lactis NCDO 763. Int J Biochem 24:707-718

Mukhurjee KK, Hutkins RW (1994) Isolation of galactose-fermenting thermophilic cultures and their use in the manufacture of low browning Mozzarella cheese. J Dairy Sci 77:2839-2849

Nájera-Domínguez C, Gutiérrez-Méndez N, Nevárez-Moorillon G, Caro-Canales I (2014) Comparison of volatile compounds produced by wild Lactococcus lactis in miniature Chihuahua-type cheeses. Dairy Sci Technol 94:499-516. doi:10.1007/s13594-014-0175-4

Nouaille S, Rault L, Jeanson S, Loubière P, Le Loir Y, Even S (2014) Contribution of Lactococcus lactis reducing properties to the downregulation of a major virulence regulator in staphylococcus aureus, the agr system. Appl Environ Microbiol 80:7028-7035

O’Bryan CA, Sostrin ML, Nannapaneni R, Ricke SC, Crandall PG, Johnson MG (2009) Sensitivity of Listeria monocytogenes Scott A to nisin and diacetyl after starvation in sodium phosphate buffered saline. J Food Sci 74:M493-M498. doi:10.1111/j.1750-3841.2009.01340.x

Oberg CJ, Merrill RK, Moyes LV, Brown RJ, Richardson GH (1991) Effects of Lactobacillus helveticus culture on physical properties of Mozzarella cheese. J Dairy Sci 74:4101-4107

OECD (2007) best practice guidelines for Biological Resource Centres www.oecd.org/sti/biotech/38777417. pdf (last accessed 17 Aug 2015)

Okada Y, Tsuzuki Y, Miyazaki J, Matsuzaki K, Hokari R, Komoto S, Kato S, Kawaguchi A, Nagao S, Itoh K, Watanabe T, Miura S (2006) Propionibacterium freudenreichii component 1.4-dihydroxy-2-naphthoic acid (DHNA) attenuates dextran sodium sulphate induced colitis by modulation of bacterial flora and lymphocyte homing. Gut 55:681-688

Papadimitriou K, Pot B, Tsakalidou E (2015) How microbes adapt to a diversity of food niches. Curr Opin Food Sci 2:29-35. doi:10.1016/j.cofs.2015.01.001

Passerini D, Beltramo C, Coddeville M, Quentin Y, Ritzenthaler P, Daveran-Mingot ML, Le Bourgeois P (2010) Genes but not genomes reveal bacterial domestication of Lactococcus lactis. PLoS ONE 5:e15306

Passerini D, Laroute V, Coddeville M, Le Bourgeois P, Loubiere P, Ritzenthaler P, Cocaign-Bousquet M, Daveran-Mingot ML (2013) New insights into Lactococcus lactis diacetyl- and acetoin-producing strains isolated from diverse origins. Int J Food Microbiol 160:329-336

Pastar I, Tonic I, Golic N, Kojic M, van Kranenburg R, Kleerebezem M, Topisirovic L, Jovanovic G (2003) Identification and genetic characterization of a novel proteinase, PrtR, from the human isolate Lactobacillus rhamnosus BGT10. Appl Environ Microbiol 69:5802-5811

Perez RH, Zendo T, Sonomoto K (2014) Novel bacteriocins from lactic acid bacteria (LAB): various structures and applications. Microbial Cell Fact 13:S3. doi:10.1186/1475-2859-13-S1-S3

Plé C, Richoux R, Jardin J, Nurdin M, Briard-Bion V, Parayre S, Ferreira S, Pot B, Bouguen G, Deutsch SM, Falentin H, Foligne B, Jan G (2015) Single-strain starter experimental cheese reveals antiinflammatory effect of Propionibacterium freudenreichii in TNBS colitis model. J Funct Foods 18:575-585

Purohit DH, Hassan AN, Bhatia E, Zhang X, Dwivedi C (2009) Rheological, sensorial, and chemopreventive properties of milk fermented with exopolysaccharide-producing lactic cultures. J Dairy Sci 92:847-856. doi: $10.3168 /$ jds.2008-1256

Richoux R, Faivre E, Kerjean JR (1998) Effet de la teneur en $\mathrm{NaCl}$ sur la fermentation du lactate par Propionibacterium freudenreichii dans des minifromages à pâte cuite. Lait 78:319-331 
Richoux R, Aubert L, Roset G, Kerjean JR (2009) Impact of the proteolysis due to lactobacilli on the stretchability of Swiss-type cheese. Dairy Sci Technol 89:31-41

Rossi F, Rizzotti L, Felis GE, Torriani S (2014) Horizontal gene transfer among microorganisms in food: current knowledge and future perspectives. Food Microbiol 42:232-243. doi:10.1016/j.fm.2014.04.004

Ryall B, Eydallin G, Ferenci T (2012) Culture history and population heterogeneity as determinants of bacterial adaptation: the adaptomics of a single environmental transition. Microbiol Mol Biol Rev 76: 597-625. doi:10.1128/MMBR.05028-11

Sadat-Mekmene L, Genay M, Atlan D, Lortal S, Gagnaire V (2011a) Original features of cell-envelope proteinases of Lactobacillus helveticus. A review. Int J Food Microbiol 146:1-13

Sadat-Mekmene L, Jardin J, Corre C, Mollé D, Richoux R, Delage M-M, Lortal S, Gagnaire V (2011b) Simultaneous presence of $\mathrm{PrtH}$ and $\mathrm{PrtH} 2$ proteinases in Lactobacillus helveticus strains improves breakdown of the pure $\alpha$ S1-casein. Appl Environ Microbiol 77:179-186

Sadat-Mekmene L, Richoux R, Aubert-Frogerais L, Madec MN, Corre C, Piot M, Jardin J, Le Feunten S, Lortal S, Gagnaire V (2013) Lactobacillus helveticus as a tool to change proteolysis and functionality in Swiss-type cheeses. J Dairy Sci 96:1455-1470

Santos-Rocha C, Lakhdari O, Blottiere HM, Blugeon S, Sokol H, Bermudez-Humaran LG, Azevedo V, Miyoshi A, Dore J, Langella P, Maguin E, van de Guchte M (2012) Anti-inflammatory properties of dairy lactobacilli. Inflamm Bowel Dis 18:657-666

Schnürer J, Magnusson J (2005) Antifungal lactic acid bacteria as biopreservatives. Trends Food Sci Technol 16:70-78. doi:10.1016/j.tifs.2004.02.014

Sheehan A, Cuinn GO, Fitzgerald RJ, Wilkinson MG (2006) Proteolytic enzyme activities in Cheddar cheese juice made using lactococcal starters of differing autolytic properties. J Appl Microbiol 100:893-901

Smit G, Smit BA, Engels WJ (2005) Flavour formation by lactic acid bacteria and biochemical flavour profiling of cheese products. FEMS Microbiol Rev 29:591-610

Smith D, McCluskey K, Stackebrandt E (2014) Investment into the future of microbial resources: culture collection funding models and BRC business plans for biological resource centres. SpringerPlus $3: 81$. doi: $10.1186 / 2193-1801-3-81$

Stackebrandt E (2011) Towards a strategy to enhance access to microbial diversity. Int J Syst Evol Microbiol 61:479-481. doi:10.1099/ijs.0.027615-0

Stackebrandt E, Frederiksen W, Garrity GM, Grimont PAD, Kämpfer P, Maiden MCJ, Nesme X, RosselloMora M, Swings J, Trüper HG, Vauterin L, Ward AC, Whitman WB (2002) Report of the ad hoc committee for the re-evaluation of the species definition in bacteriology. Int J Syst Evol Microbiol 52: 1043-1047. doi:10.1099/ijs.0.02360-0

Staley JT, Krieg NR (1984) Classification of procaryotic organisms: an overview. In: Krieg NR, Holt JG (eds) Bergey's Manual of Systematic Bacteriology, vol 1. The Williams \& Wilkins Co., Baltimore, pp 1-4

Suzuki A, Mitsuyama K, Koga H, Tomiyasu N, Masuda J, Takaki K, Tsuruta O, Toyonaga A, Sata M (2006) Bifidogenic growth stimulator for the treatment of active ulcerative colitis: a pilot study. Nutrition 22:76-81

Tanous C, Kieronczyk A, Helinck S, Chambellon E, Yvon M (2002) Glutamate dehydrogenase activity: a major criterion for the selection of flavour-producing lactic acid bacteria strains. Anton Leeuw Int J G 82: 271-278

Taverniti V, Stuknyte M, Minuzzo M, Arioli S, De Noni I, Scabiosi C, Cordova ZM, Junttila I, Hamalainen S, Turpeinen H, Mora D, Karp M, Pesu M, Guglielmetti S (2013) S-layer protein mediates the stimulatory effect of Lactobacillus helveticus MIMLh5 on innate immunity. Appl Environ Microbiol 79:1221-1231

Thierry A, Maillard MB, Hervé C, Richoux R, Lortal S (2004a) Varied volatile compounds are produced by Propionibacterium freudenreichii in Emmental cheese. Food Chem 87:439-446

Thierry A, Richoux R, Kerjean JR, Lortal S (2004b) A simple screening method for isovaleric acid production by Propionibacterium freudenreichii in Swiss cheese. Int Dairy J 14:697-700

Thierry A, Maillard MB, Richoux R, Kerjean JR, Lortal S (2005) Propionibacterium freudenreichii strains quantitatively affect production of volatile compounds in Swiss cheese. Lait 85:57-74

Thierry A, Berthier F, Gagnaire V, Kerjean JR, Lopez C, Noël Y (2010) Eye formation and Swiss-type cheeses. In: Law BA, Tamime AY (eds) Technology of cheesemaking. Wiley-Blackwell, pp. 360-383

Thierry A, Deutsch SM, Falentin H, Dalmasso M, Cousin F, Jan G (2011a) New insights into physiology and metabolism of Propionibacterium freudenreichii. Int J Food Microbiol 149:18-27

Thierry A, Falentin H, Deutsch SM, Jan G (2011)b Bacteria, beneficial: Propionibacterium spp. In: Fuquay JW, Fox PF, McSweeney P (eds) Encyclopedia of Dairy Science. Elsevier, pp. 403-411

Turgay M, Irmler S, Isolini D, Amrein R, Fröhlich-Wyder MT, Bertoud H, Wagner E, Wechsler D (2011) Biodiversity, dynamics, and characteristics of Propionibacterium freudenreichii in Swiss Emmentaler PDO cheese. Dairy Sci Technol 91:471-489. doi:10.1007/s13594-011-0024-7

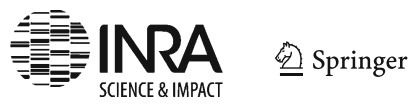


Uchida M, Mogami O (2005) Milk whey culture with Propionibacterium freudenreichii ET-3 is effective on the colitis induced by 2,4,6-trinitrobenzene sulfonic acid in rats. J Pharmacol Sci 99:329-334

Umamaheswari T, Anbukkarasi K, Singh P, Tomar SK, Singh R (2014) Streptococcus thermophilus strains of plant origin as dairy starters: isolation and characterisation. Int J Dairy Technol 67:117-122

Urbach G (1997) The flavour of milk and dairy products: II. Cheese: contribution of volatile compounds. Int J Dairy Technol 50:79-89

Valence F, Richoux R, Thierry A, Palva A, Lortal S (1998) Autolysis of Lactobacillus helveticus and Propionibacterium freudenreichii in Swiss cheeses: first evidence by using species-specific lysis markers. J Dairy Res 65:609-620

Valence F, Deutsch SM, Richoux R, Gagnaire V, Lortal S (2000) Autolysis and related proteolysis in Swiss cheese for two Lactobacillus helveticus strains. J Dairy Res 67:261-271

Vassal L, Gripon JC (1984) L'amertume des fromages à pâte molle de type camembert. Lait 64:397-417

Vinogradov E, Valence F, Maes E, Jebava I, Chuat V, Lortal S, Grard T, Guerardel Y, Sadovskaya I (2013) Structural studies of the cell wall polysaccharides from three strains of Lactobacillus helveticus with different autolytic properties: DPC4571, BROI, and LH1 320. Carbohydr Res 379:7-12

Wu Q, Cheung CKW, Shah NP (2015) Towards galactose accumulation in dairy foods fermented by conventional starter cultures: challenges and strategies. Trends Food Sci Technol 41:24-36. doi:10. 1016/j.tifs.2014.08.010

Wyder MT, Bosset JO, Casey MG, Isolini D, Sollberger H (2001) Influence of two different propionibacterial cultures on the characteristics of Swiss-type cheese with regard to aspartate metabolism. Milchwissenschaft 56:78-81

Yamashita M, Ukibe K, Uenishi H, Hosoya T, Sakai F, Kadooka Y (2014) Lactobacillus helveticus SBT2171, a cheese starter, regulates proliferation and cytokine production of immune cells. J Dairy Sci 97:47724779

Yee A, Maillard MB, Roland N, Chuat V, Leclerc A, Pogacic T, Valence F, Thierry A (2014) Great interspecies and intraspecies diversity of dairy propionibacteria in the production of cheese aroma compounds. Int J Food Microbiol 191:60-68

Yvon M, Rijnen L (2001) Cheese flavour formation by amino acid catabolism. Int Dairy J 11:185-201 